Journal of

Food and Nutrition

\title{
Correlation between Dietary Patterns \& Bone Mineral Density in Women from Adulthood to Menopause: a Descriptive Study
}

\section{Zarnain Ali Shah ${ }^{1, \star}$, Farhan Mukhtar ${ }^{2}$, Tariq Ismail ${ }^{3}$}

${ }^{1}$ Senior Clinical Nutritionist/ Incharge of Food and Nutrition Department Multan College of Food and nutrition, Multan Medical and Dental institute, Multan

${ }^{2}$ Assistant Professor, Multan college of Nursing, Multan Medical and Dental institute, Multan

${ }^{3}$ Assistant Professor, Department of Food and Nutrition, Bahaudin Zakariya University, Multan

${ }^{\star}$ Corresponding author: Zarnain Ali Shah, Senior Clinical Nutritionist/ Incharge of Food and Nutrition Department Multan College of Food and nutrition, Multan Medical and Dental institute, Multan; Email ID: Zarnainali85@yahoo.com

Received Date: September 18, 2019 Accepted Date: October 01, 2019 Published Date: October 03, 2019

Citation: Zarnain Ali Shah (2019) Correlation between Dietary Patterns \& Bone Mineral Density in Women from Adulthood to Menopause: a Descriptive Study. J Food Nutr 5: 1-6.

\begin{abstract}
Objective: To assess the impact of dietary trends/habits on Bone Mineral Density through various life stages of women.

Methods: The descriptive cross-sectional research design was used. One hundred \& eighty subjects were subjected as a sample population of this particular research. This study sample population was further divided into three groups based on age 19-44, 45-55, 56-70 year. Data were collected through self-explanatory questionnaire. Each patient BMI was calculated. Complete blood count (CBC) and Serum Calcium Level (SCL), lab tests of each patient was performed.

Results: on-significant differences in bone mineral density of women in age from 19 - 70 year i.e. adulthood to post-menopause were seen. However, reduction in the bone mineral can be evidently witnessed among the three groups describing a reduction in bone mineral density to be associated with progression of age. Least bone mineral density was noticed in women in age between 55 - 70 year as compared to women in age between 19-44.

Conclusion: The results of this study indicate that there is no significant relationship between different age groups of women and BMD. Diet has a strong role to play in the BMD of patients. The major dietary component that can play a significant role in bone structure building and bone health maintenance include proteins and a greater amount of micronutrients particularly calcium, phosphorus, magnesium, zinc and vitamin D.
\end{abstract}

Keywords: Bone Mineral Density

(C)2019 The Authors. Published by the JScholar under the terms of the Creative Commons Attribution License http://creativecommons.org/licenses/ by/3.0/, which permits unrestricted use, provided the original author and source are credited. 


\section{Introduction and Literature Review}

Osteoporosis is a bone disorder characterized by poor bone quality and concentration, and a higher risk of fracture due to skeleton weakness, most of the hip, wrist, and spine [1]. Osteoporosis is usually mentioned as a 'silent disease' because it does not reveal any symptoms until a fracture happens. Morbidity and disability are the main reasons for osteoporotic fractures in older people [2]. In 2000, there were around 9 million osteoporotic fractures discovered globally whereas the distribution of population with osteoporotic fracture had been reported with around 2000 million cases among women since [3].

Diet is a modifiable factor and has an important role in bone health insurance and maintenance. The major dietary component that can play a significant role in bone structure building and bone health maintenance include proteins and a greater amount of micronutrients particularly calcium, phosphorus, magnesium, zinc and vitamin D [4]. It has been widely reported that calcium and vitamin D have significant importance in bone health, and supplements having these nutrients are broadly recommended by the physicians, nutritionists and other health practioners [5].

The research-based findings emphasize healthier diet intake to have remarkable relation with both longitudinal and cross-sectional change in bone mineral density (BMD). Many factors are involved in the growth and loss of bone mass including age, gender, ethnicity, heredity, lifestyles (physical activity, smoking, and alcohol intake) and nutritional status (calcium, protein and vitamin D intake [6]. Approximately, 1000 to 1200 $\mathrm{mg} /$ day calcium is suggested for older people at higher risk of osteoporosis [7].

Diet plays an important role in the treatment of osteoporosis. Many types of fat are positively associated with bone health, such as polyunsaturated fatty acid considered beneficial in the management of osteoporosis Fruit and vegetable intake may protect against premenopausal bone loss [8].

\section{Research Methodology}

\section{The objective of Study}

To assess the impact of dietary trends/habits on BMD through various life stages of women.

\section{Study design}

The descriptive, cross-sectional study design was con- ducted for the present study.

\section{Study Population}

Female patients from 19-70 year were the target group. One hundred \& eighty indoor/outdoor female patient of Ibn-eseina (Teaching hospital) Multan were enrolled in the study [26].

\section{Sampling Technique}

Convenient sampling technique is used for data collection.

\section{Selection and Development of the Tool}

The tool used for the present study was a selfadministered questionnaire. The weight machine was used for measuring weight. The measuring tape was used for measuring height. Body mass index was calculated as the weight divided by the height squared $(\mathrm{kg} / \mathrm{m} 2)$. A self-reported questionnaire was used to acquire information on known risk factors for bone health, including health-related lifestyles (smoking, alcohol consumption and physical activity), reproductive history for women and medical history in general. After completion of the questionnaire, a face-to-face interview was performed to clarify incomplete or ambiguous responses. CBC and SCL test were performed upon all subjects to get baseline data.

\section{Validity and reliability of the tool}

The study tool was reviewed and validated by experts in public health and statistician. The questionnaire was then pilot tested amongst a group of the patient $(n=20)$. This process ensured that the questionnaire was understandable and concise. Reliability of the tool was computed using Cronbach's. The results of the pilot study showed an internal consistency of 0.726 which showed that the tool was reliable for data collection.

\section{Data Analysis}

Data were analyzed using descriptive statistics by computing frequencies, mean and standard deviation and has been presented in the form of tables.

The findings begin with a description of the respondent profile based on the total of 180 questionnaires returned.

\section{Bone mineral density of the women}

The data presented in Table 1.1 present non-significant differences in bone mineral density of women in age from 19 70 year i.e. adulthood to post-menopause. Least to no difference in bone mineral density was noticed in three age groups i.e. 19 
$-44 \mathrm{Y}, 45-55 \mathrm{Y}$ and $55-70 \mathrm{Y}$.

Table1.1: Bone mineral density of women at different life stages

\begin{tabular}{lll}
\hline Age group & Age & Mean BMD (\%) \\
\hline A & $19-44$ & $73.24 \pm 2.39 \mathrm{a}$ \\
B & $45-55$ & $67.14 \pm 3.23 \mathrm{a}$ \\
C & $55-70$ & $59.35 \pm 9.42 \mathrm{a}$ \\
\hline
\end{tabular}

Values sharing the same lettering in a column do not differ significantly at $\mathrm{p}<0.05$

However, reduction in the bone mineral can be witnessed among the three groups describing a reduction in bone mineral density to be associated with progression of age. Least bone mineral density was noticed in women in age between 55 - 70 year as compared to women in age between 19-44.
Table: 1.2Analysis of variance for mean bone mineral density at various life stages of women

\begin{tabular}{llllll}
\hline Source & DF & SS & MS & F & P \\
\hline Group & 2 & 671.13 & 335.6 & 1.89 & 0.163 \\
Error & 47 & 8347 & 177.614 & & \\
Total & 49 & 9019 & & & \\
\hline
\end{tabular}

\section{Correlation between diet and bone mineral density:}

Diet has been referred to be a hallmark in either improved or bad nutritional status of communities belonging to different genders, age, regions, and ethnicity [9]. Poor bone mineral density leading to the osteoporotic condition has a very strong correlation with diet.

Table 1.3: Correlation matrix for bone mineral density and diet of women from adolescence to menopause

\begin{tabular}{|c|c|c|c|c|c|c|c|c|c|c|}
\hline Food & $\begin{array}{l}\text { Dairy } \\
\text { Prod- } \\
\text { ucts }\end{array}$ & $\begin{array}{l}\text { Meat } \\
\text { Prod- } \\
\text { ucts }\end{array}$ & $\begin{array}{l}\text { Vegeta- } \\
\text { bles }\end{array}$ & Fruits & $\begin{array}{l}\text { Fried } \\
\text { Food }\end{array}$ & $\begin{array}{l}\text { Bev- } \\
\text { erag- } \\
\text { es }\end{array}$ & $\begin{array}{l}\text { Confec- } \\
\text { tionary }\end{array}$ & Snacks & $\begin{array}{l}\text { Fast } \\
\text { Food }\end{array}$ & $\begin{array}{l}\text { Choc- } \\
\text { olate }\end{array}$ \\
\hline $\begin{array}{l}\text { Dairy Prod- } \\
\text { ucts }\end{array}$ & 1.000 & -.035 & .184 & .372 & .260 & .062 & -.025 & .184 & -.012 & .168 \\
\hline $\begin{array}{l}\text { Meat Prod- } \\
\text { ucts }\end{array}$ & -.035 & 1.000 & -.283 & -.048 & .175 & .115 & .242 & .272 & .298 & -.122 \\
\hline Vegetables & .184 & -.283 & 1.000 & .190 & -.245 & -.274 & -.256 & -.316 & -.478 & .116 \\
\hline Fruits & .372 & -.048 & .190 & 1.000 & -.093 & -.205 & -.011 & .071 & .021 & -.061 \\
\hline Fried Food & .260 & .175 & -.245 & -.093 & 1.000 & .460 & .401 & .382 & .224 & .091 \\
\hline Beverages & .062 & .115 & -.274 & -.205 & .460 & 1.000 & .373 & .475 & .364 & .232 \\
\hline $\begin{array}{l}\text { Confection- } \\
\text { ary }\end{array}$ & -.025 & .242 & -.256 & -.011 & .401 & .373 & 1.000 & .514 & .487 & -.015 \\
\hline Snacks & .184 & .272 & -.316 & .071 & .382 & .475 & .514 & 1.000 & .535 & .131 \\
\hline Fast Food & -.012 & .298 & -.478 & .021 & .224 & .364 & .487 & .535 & 1.000 & .321 \\
\hline Chocolate & .168 & -.122 & .116 & -.061 & .091 & .232 & -.015 & .131 & .321 & 1.000 \\
\hline
\end{tabular}

The results show a positive and negative correlation between various dietary components and bone mineral density at various life stages of women. Foods like dairy, meat, fruits, vegetables, and chocolates have a definitive role in BMD at different stages of life. Consumption of dairy products added toward improved bone mineral density whereas incorporation of other foods like fruits, chocolate, and vegetables was also found to be moderate to weakly associate with building BMD profile. Interestingly it was observed in data that, meat products once eating with vegetables have a strong negative effect on BMD, along with fast foods. 
Fruits consumption with dairy products and various vegetables was also found to be positively associated with improved bone mineral density [10].

\begin{tabular}{|ll|}
\hline $\begin{array}{l}\text { Range of correlation } \\
\text { coefficient }\end{array}$ & Degree of correlation \\
\hline $0.80-1.0$ & Very strongly correlate (positive) \\
$0.40-0.59$ & Moderately correlate (positive) \\
$0.00-0.19$ & Very weak correlate (positive) \\
$0.00-(-0.19)$ & Very weak (negative) \\
$-0.40-(-0.59)$ & Moderate (negative) \\
$-0.80-(-1.0)$ & Very strongly (negative) \\
\hline
\end{tabular}

Table 1.4

\section{Discussion}

Osteoporosis is a bone disorder characterized by poor bone quality and concentration, and a higher risk of fracture due to skeleton weakness, most of the hip, wrist, and spine [1-11]. Osteoporosis is usually mentioned as a 'silent disease' because it does not reveal any symptoms until a fracture happens [12]. Prevalence of osteoporosis and occurrence of osteoporosis-related fractures are becoming main social and medical worries in both developed and developing countries as the population grows older [13].

Diet is a modifiable factor and has an important role in bone health insurance and maintenance [14, 19]. The major dietary component that can play a significant role in bone structure building and bone health maintenance include proteins and a greater amount of micronutrients particularly calcium, phosphorus, magnesium, zinc and vitamin D [15]. It has been widely reported that calcium and vitamin $\mathrm{D}$ have significant importance in bone health, and supplements having these nutrients are broadly recommended by the physicians, nutritionists and other health practitioner [16-18].

The study indicated dietary menus with adequate dairy, meat, fruits, vegetables, and chocolates to add a positive change in bone mineral density of the studies population [20]. Consumption of dairy products added toward improved bone mineral density whereas incorporation of other foods like fruits, chocolate, and vegetables was also found to be moderate to weakly associate with building bone mineral profile [21-22]. Negative correlation indicating the inverse impact on dairybased meals was witnessed from confectionary, fast foods and even meat-based recipes consumption [23].

\section{Recommendations}

Bone mineral density represents the bone strength of individuals. It is said to be linked with intake of calcium and vitamin D. Regular and sufficient intake of these nutrients must be ensured, especially during pregnancy or lactation, either through diet or supplements to avoid any losses in bone strength. For maintaining bone strength, the dietary pattern of individuals plays an important role [24]. The use of cola beverages must be minimized because of their severe harmful impacts on bone strength. Moreover, a healthy diet, including dairy products, fruits and vegetables, and other protein-rich sources must be adapted as a protective factor for bone health. In contrast, regular consumption of fast food, red meat, and caffeine-rich commodities should be prevented. Smoking and alcohol consumption are negatively linked with BMD, so such must be avoided as well [25].

\section{Conclusion}

This study reports a positive relationship with dietary habits and BMD at various ages of the life span of women. Dietary patterns can't exclusively be considered a factor which affects BMD in women of different ages. A healthy lifestyle is also critical for BMD. Regular physical exercise helps to enhance the deposition of calcium making the bones stronger. A sedentary lifestyle must not be adapted to prevent any issues as far as bone strength is concerned. Furthermore, optimum exposure to sunlight is also important for females as the majority of them tend to stay indoors due to cultural norms in the region.

\section{Acknowledgments}

The authors are thankful to the administration of the participating hospital for their facilitation and cooperation to conduct this study. 


\section{References}

1. Melton LJ, Atkinson EJ, O'connor MK, O'fallon WM, \& Riggs BL (1998) Bone density and fracture risk in men. Journal of Bone and Mineral Research 13: 1915-1923.

2. Plawecki K \& Chapman-Novakofski K (2010) Bone health nutrition issues in aging. Nutrients, 2: 1086-1105.

3. Kanis JA, Johnell O, Oden A, Johansson H, \& McCloskey $\mathrm{E}$ (2008) $\mathrm{FRAX}^{\mathrm{Tm}}$ and the assessment of fracture probability in men and women from the UK. Osteoporosis International 19: 385-397.

4. Bonjour JP, Guéguen L, Palacios C, Shearer MJ, \& Weaver CM (2009) Minerals and vitamins in bone health: the potential value of the dietary enhancement. British journal of nutrition 101: 1581-1596.

5. Tai V, Leung W, Grey A, Reid IR \& Bolland MJ (2015) Calcium intake and bone mineral density: systematic review and meta-analysis. BMJ, 351, h4183.

6. Albertazzi P \& Coupland K (2002) Polyunsaturated fatty acids. Is there a role in postmenopausal osteoporosis prevention?. Maturitas 42: 13-22.

7. Cummings SR \& Melton LJ (2002) Epidemiology and outcomes of osteoporotic fractures. Lancet, 359: 1761-1767.

8. Daniel M, Martin AD, Drinkwater DT (1992) Cigarette smoking, steroid hormones, and bone mineral density in young women. Calcif Tissue Int 50: 300-305.

9. Dulloo AG, Seydoux J, Girardier L, Chantre P \& Vandermander J (2000) Green tea and thermogenesis: interactions between catechin-polyphenols, caffeine, and sympathetic activity. International journal of obesity 24: 252.

10. Greenspan SL, Bone HG, Ettinger MP, Hanley DA, Lindsay R, et al. (2007) Effect of Recombinant Human Parathyroid Hormone (1-84) on Vertebral Fracture and Bone Mineral Density in Postmenopausal Women with Osteoporosis A Randomized Trial Treatment of Postmenopausal Osteoporotic Women with Parathyroid Hormone (1-84). Annals of internal medicine 146: 326-339.

11. Gullberg B, Johnell, O, \& Kanis JA (1997) The worldwide projection for hip fracture. OsteoporosInt 7: 407-413.

12. Gunn CA, Weber JL, \& Kruger MC (2014) Diet, weight, cytokines and bone health in postmenopausal women. The journal of nutrition, health \& aging 18: 479-486.

13. Hannan MT, Tucker KL, Dawson-Hughes B, Cupples LA, et al. (2000) Effect of Dietary Protein on Bone Loss in Elderly Men and Women: The Framingham Osteoporosis Study. JBMR 15: 2504-2512.

14. Hardcastle AC, Aucott L, Fraser WD, et al. (2011) Dietary patterns, bone resorption and bone mineral density in early postmenopausal Scottish women. European journal of clinical nutrition 65: 378 .

15. Kiel DP, Baron JA, Anderson JJ, Hannan MT, Felson DT (1992) Smoking eliminates the protective effect of oral estrogens on the risk for hip fracture among women. Ann Intern Med 116: 716-721.

16. Krall EA, Dawson-Hughes B (1991) Smoking and bone loss among postmenopausal women. J Bone Miner Res 6: 331338.

17. Lloyd JT, Alley DE, Hochberg MC, Waldstein SR, Harris TB, Kritchevsky, et al. (2016) Changes in bone mineral density over time by body mass index in the health ABC study. Osteoporosis International 27: 2109-2116.

18. Macdonald HM, New SA, Golden MH, Campbell, et al. (2004) Nutritional associations with bone loss during the menopausal transition: evidence of a beneficial effect of calcium, alcohol, and fruit and vegetable nutrients and of a detrimental effect of fatty acids. The American journal of clinical nutrition 7: 155165.

19. Mazess RB, Barden HS (1991) Bone density in premenopausal women: effects of age, dietary intake, physical activity, smoking, and birth control pills. Am J ClinNutr 53: 132-142.

20. McCulloch RG, Whiting SJ, Bailey DA, Houston CS (1991) The effect of cigarette smoking on trabecular bone density in premenopausal women aged 20-35 years. Can J Public Health 82: 434-435.

21. Shin S, Sung J, \& Joung H (2015) A fruit, milk and whole-grain dietary pattern are positively associated with bone mineral density in Korean healthy adults. European journal of clinical nutrition 69: 442.

22. Tai V, Leung W, Grey A, Reid, I. R, \& Bolland MJ (2015) Calcium intake and bone mineral density: systematic review and meta-analysis. BMJ 351, h4183.

23. Tang YJ, Sheu WHH, Liu PH, Lee WJ, et al. (2007) Positive associations of bone mineral density with body mass index, physical activity, and blood triglyceride level in men over 70 years old: a TCVGHAGE study. Journal of bone and mineral metabolism 25: 54-59.

24. Wee J, Sng BYJ, Shen L, Lim, CT, Singh G, et al. (2013) The relationship between body mass index and physical activity levels with bone mineral density in premenopausal and postmenopausal women. Archives of osteoporosis 8: 162.

25. Wyshak G (2000) Teenaged girls, carbonated beverage consumption, and bone fractures. Archives of pediatrics \& adolescent medicine 154: 610-613. 
Submit your manuscript to a JScholar journal and benefit from:

I Convenient online submission

I Rigorous peer review

- Immediate publication on acceptance

- Open access: articles freely available online

I. High visibility within the field

- Better discount for your subsequent articles

Submit your manuscript at http://www.jscholaronline.org/submit-manuscript.php 